文辡

1）後藤共子，長野正满，結城康夫，故小田隆，高井 博和; 緎学読，31，36(1975)

2) 後藤其子, 長野正满, 村上一; 瀻学誌， 31，T$250, T-367(1975)$

3）後藤共子，長野正满，田中敬造; 瀻学誌, 31，T$121(1975)$

4) 日本材料学会綟 “X楾底力測定法”，羕賢堂 (1966)

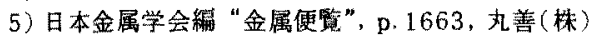
(1971)

6) 代勇“X線結晶学”下, p. 58，70，611，九善 (株) $(1961)$

7) 後藤 徹 "材料"，21，876(1972)，21，960 (1972)

8) Brill, R., Zett Krist., 68, 387 (1928)

9) R. Ramachandraroo, T.R. Anantharaman, Trans. TMS $A I M E v, 245,892$ (1969)

10）日本金属学会“金属便覧”，p. 1452 ，九善（蛛）
(1971)

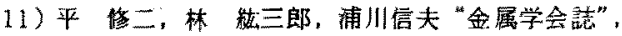
35, 197(1971)

12) 日本化学会編 "化学便覧”，p. 477, 丸善(制) (1966)

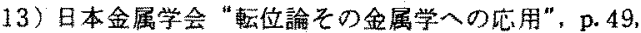
627, 丸善(株) (1971)

14）鈴木 平“日本金属学全会埾”，2，174（1963）

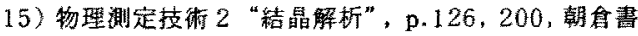
忘 (1966)

16) D.R. Clark, A. Howie, Phil. Mag., 24, 959 (1971)

17) D.R. Clark, Phil. Mag., 24, 973 (1971)

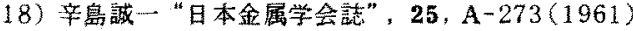

19) J.J. Gilman, W.G. Johnston, Dislocations in LiF crystala, Solid state Phys., 13. Academic press Inc., N.Y. (1962) 148

20)平修二，吉岡靖夫“日本機诚学会諭文集”， 30 ， $1142(1964)$

21）細川智生，信長覚子“材料”，18，24（1969）

(昭和50年4月10日受畦)

\title{
アクリル繊維の抗ピル化機構とその評価方法*
}

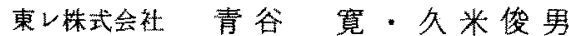

\section{THE MECHANISM AND THE EVALUATION METHOD OF PILLING TENDENCY}

\author{
By Hiroshi Aotani* and Toshio Kume** \\ * (Fibers and Textiles Research Labs., Toray Industries, Inc., \\ 1515 Masaki-cho, Iyogun, Ehime Prefecture, Japan) \\ ** (Seta Plant, Toray Inds. Inc., \\ 1234-1 Seta-Oe-cho, Otsu City, Shiga Prefecture, Japan)
}

For the purpose of improvement of piling tendency of acrilic fiber, many studies have been reported. However they seem not to be successful due to poor testing method at the stage of staple fiber. In this work the new pill-testing method of staple fiber (SF-pill-test) is proposed as a useful technique to estimate the pilling tendency of woven and knitted fabrics.

If pill formation and wearing-off process proceeds as shown below, theoretical equation may be introduced.

\footnotetext{
*この報文を「抗ビル性アクリル瀻維に関する研究(第1報) Studies on the anti-pilling acrylic fibers」 亡する。 

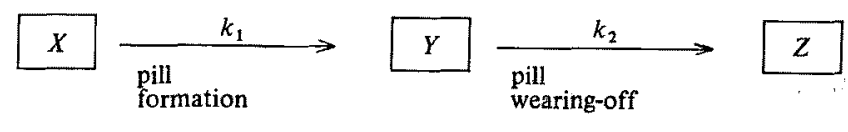

$\begin{aligned} & \text { Number of } \\ & \text { pillable } \\ & \text { fuzz as pill }\end{aligned}$
$y=\frac{k_{1} X_{0}}{-k_{1}+k_{2}}\left(e^{\left.-k_{1} t-e-k_{2} t\right)}\right.$

$k_{1}$ : rate constant of pill formation

$k_{2}: \quad$ rate constant of pill wearing-off

By application of the data from SF-pill-test to the equation, $k_{2}$ and HWT can be calculated. Improvement of pilling tendency will be expected from larger $k_{2}$ and smaller HWT.

(Received April 10, 1975)

\section{1. 緒訔}

フクリル絨維が工業化されて以来すでに 20 年以上を 経過し，現在では 3 大合成繊維の一角を占めるに至って いるが，その過程におおては数多くの曲折を経て問題点 を克服してきた。フィブリル化，染色性は共重合組成に まてさかのぼることにより，またハイバルキ一化は製芽 プロセスを変更することにより達成された。

一方合成瀻維出現の当初から衣料として大きな問題点 とされた欠点の一つとして抗ビル性不良がある。ボリエ ステルをはじめナイロンにおいても大きな問題ではある が，ステープルタイプで編成品主体のアクリル織維の場 合は特にこの偭向は大きく，改善が必要とされていた。

抗ピル性を改善する方法として

(1) 毛羽発生防此

(2) 毛羽からみ防止

(3) ビル脱落助長 2 )

の3法があり，それぞれの方法に関して数多くの害験が なされている。しかしながら毛羽発生を防此して抗ピル 性を達成させようとする場合、いわゆるフィラメントラ イクにすることによりステーブル特有の風合，あたたか み等が失われ棓品便として好ましいものにならない こと，毛羽は発生してもそれらがからみ合わないように する力法は，系の断面形状，㣚性にかかかる問題であり 実現が困難である。そのため瀻維の抗ピル化は大部分が 第三の万法であるビル脱落を助長する万法で進められて いる。

抗ビル化研究を進める場合の大きな障害の一つは，ピ リンクという現象が㵶維集合体のからみ合いという複雑 な現象豙であるため，その評価方法が確立されていない
ことにある。従来から用いられている一般的な方法は， 強伸度，結節強伸度，屈曲摩耗強度"，ループローク強 度”。るいはその組合せによるもの゙であり，いずれも 単織維の何らかの力学的性質で抗ピル性を推定しょうと するものである。しかし衣料となった製品の抗ピル性と これらの単純化された各物性值の間の相関性が十分では ないのは勿論，抗ピル性と単緎維物性との間の物理的意 味づけがなされにくく説得力のある特性值とはなりにく いきらいがあり，いかにして単緎維段階（原綿段階）て 適奶な抗どル性評洒をするという点に大きなボイントが あったと思われる。

著者らは，本報に扔いてピリング現象を理論的に解析 することおよびその理論を寒験的に証明することにより， 物理的な意味づけを明確化するとともに，原綿段揩て抗 ピル性を評価する有効な尺度を見出したので報告する。 本報はつクリル緎維の抗ピル化研究の第一歩であり， 続報としてこれを基準尺度とした抗ピル化方法について 豗次報告していく予定である。

\section{2. ピル生成, 脱落の理論と解釈}

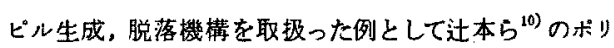
エステル混紡織物の現象論的考察があり，ピルの形態的 な観察が詳細になされているが杭ビル性という角度から の検討は少ない。また動力学的に取报った例としてR. H. Brand ${ }^{7)}$ ののモデルがある。彼等恃䄉編物から毛羽 が発生し，ピルとなり脱落するまてに生ずるであるらす べての現象に一次の速度式をあてはめ, それぞれ速度定 数による状態式を導くことを試みこれを実験的に説明し ようとしているが，実際にはきわめて実験困難な内子 （例えばビルとならないで脱落する毛羽の量）が含まれ 
ているため底用面では問題が多い。

そこて著者ら流より実験しやすい理諭式を䄈入するた め，次の上うな仮説の下でピル生成，脱落のブロセスを 考元速度論的な解析老試子た。

まず，ピル生成脱落は次のステージで進むとする。

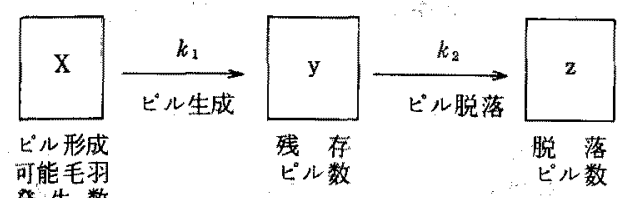

発生数

$$
\left(\begin{array}{l}
k_{1}: \text { ピル生成速度定数 } \\
k_{2}: ヒ^{\circ} \text { ル脱落速度定数 }
\end{array}\right)
$$

\section{ここで炊の仮定をおく。}

\section{纳説一 1.}

ピル形成可能毛抿数仙一定 $\left(X=X_{0}\right)$

すなわちアクリル織維を抗ビル化する場合，ピル形成 可能毛羽数を減少させるのではなく，十分な毛羽が発生 しそれがビルとなっても脱落が速いことにより抗ビル化 されることを前提としている。

仮説 - 2.

ピル形成可能毛羽はすべてピルとなり終局的にはすべ て脱落する $\left(z_{t-\infty}=X_{0}\right)$

仮説 - 3.

次の速度式が成立するとする。

$$
\begin{aligned}
& -\frac{d x}{d t}=k_{1} x \\
& \frac{\partial y}{\partial t}=k_{1} x-k_{2} y \\
& \frac{\partial z}{\partial t}=k_{2} y
\end{aligned}
$$

仮説一1，2加喑界条件は

$$
\left(\begin{array}{lll}
t=0: x=X_{0} & y=0 & z=0 \\
t=\infty: x=0 & y=0 & z=X_{0}
\end{array}\right)
$$

となる。

ここで倔徽分方程式を解く。

(1)式につい下

$$
x=C e^{-k_{1} t}
$$

ここで $t=0 \rightarrow x=X_{0}$ であるから $C_{1}=X_{0}$

(4) 武は

$$
x=X_{0} e^{-k_{1} t}
$$

(2) 式以ついて

(5)を(2)に代入して

$$
\begin{aligned}
& \frac{d y}{d t}=k_{1} X_{0} e^{-k_{1} t}-k_{2} y \\
& \frac{d y}{d t}+k_{2} y=k_{2} X_{0} e^{-k_{1} t} \\
& y e^{k_{2} t}=\frac{k_{3} X_{0}}{-k_{1}+k_{2}} e^{\left(-k_{1}+k_{2}\right) t}+C_{2} \\
& y=\frac{k_{1} X_{0}}{-k_{1}+k_{2}} e^{-k_{1} t}+C_{2} e^{-k_{2} t}
\end{aligned}
$$

$こ こ て ゙=0 \rightarrow y=0$ とおけば $C_{2}=\frac{-k_{2} X_{0}}{-k_{1}+k_{2}}$ となり

$$
y=\frac{k_{1} X_{0}}{-k_{1}+k_{3}}\left[e^{-k_{1} t}-e^{-k_{2} t}\right]
$$

(3)式について

(9)式を代入することにより

$$
\begin{gathered}
\frac{d z}{d t}=\frac{k_{1} k_{2} X_{0}}{-k_{1}+k_{2}}\left[e^{-k_{1} t}-e^{-k_{2} t}\right] \\
z=\frac{k_{2} k_{2} X_{0}}{-k_{1}+k_{2}}\left[-\frac{e^{-k_{1} t}}{k_{2}}+\frac{e^{-k_{2} t}}{k_{2}}\right]+C_{3} \\
こ こ て ゙ t=0 \rightarrow z=0 \text { とおけば } C_{3}=X_{0} \text { となり } \\
z=\frac{k_{1} k_{2} X_{0}}{-k_{1}+k_{2}}\left[-\frac{e^{-k_{1} t}}{k_{1}}+\frac{e^{-k_{2} t}}{k_{2}}\right]+X_{0}
\end{gathered}
$$

上式の中で特に重要な式㹸ピルの存在状態を示す（9) 式でありこれについて梤討してみる必要がある。

(9) 式の $k_{1} ， k_{3}$ に任意の数值をあては好て理論曲線

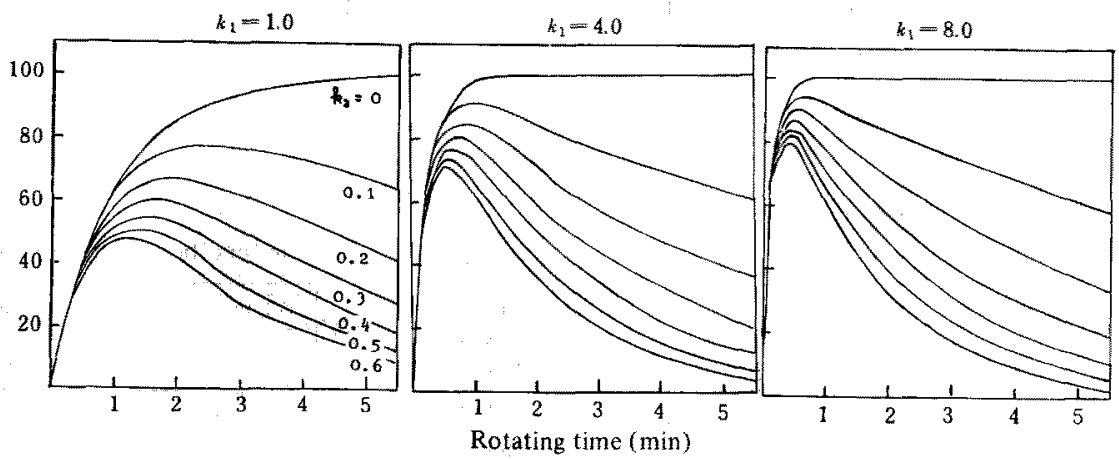

Fig. 1 Simulation of pill life curve from theoretical equation 
を画いてみる。今 $X_{0}=100$ と標準化し $k_{1}$ を $1.0 \sim 8.0$, $k_{2}$ を0.1〜0.6の範囲でシミュレーションカーブを画く と図 $1 \mathrm{a} \sim \mathbf{c}$ となる。これらのシミュレーションカーブ (理論ピルライフ曲線) から得られる情報は次の事項で ある。

（1） $k_{2}$ にかかわらず $k_{1}$ はほぼ一定であり，これは 初期の立上りカーブと対応している。すなわち， $t=\frac{1}{10}$, あるいは $\frac{1}{4} \min$ 時のピル数と $k_{1}$ には図 2 の関係があり， 実験值からピル数がわかれば $k_{1}$ を求めることができる。

(2) $k_{2}$ は $k_{1}$ をパラメータとして後半の右下りカーブ と対応している。 $t=4,5 \mathrm{~min}$ 時のピル数と $k_{2}$ とは図 3 $\mathrm{a}, \mathrm{b}$ の関倸があり, 実験值から所定の $k_{1}$ の曲線をあて はめることにより

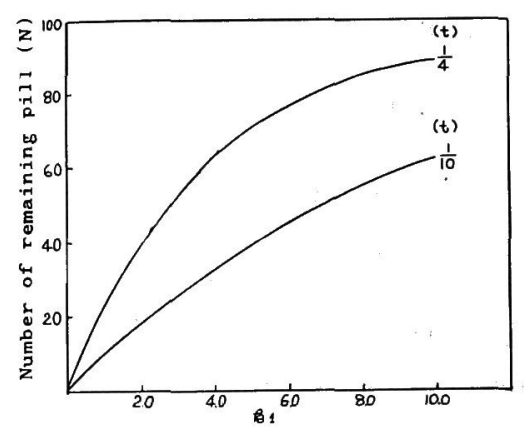

Fig. 2 Relation between $k_{1}$ and theoretical pill life curve

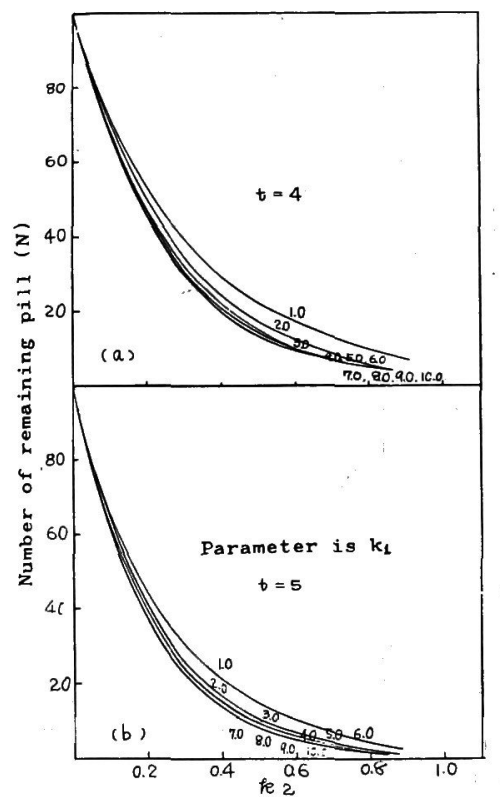

Fig. 3 Relation between $k_{2}$ and theoretical pill life curve

$$
k_{2}=\frac{1}{2}\left[k_{2}(t=4)+k_{2}(t=5)\right]
$$

として求めることができる。測定誤差を少なくする意味 で2点の平均値を求めている。

\section{SF ピルテスタによる実験値のあてはめ}

\section{1 実験方法}

SF (Staple Fiber)ピルテスタ"および測定方法に ついてのべる。本実験に用いた SF ピルテスタは図 4 a ーbに外観を示す。図 4 a はART (appearance Retention Tester) ピリング試験機の外観であり，図 $4 \mathrm{~b}$ はホルダ部分である。

測定条件は表 1 のとおり。

サンブルはデニール，カット長とも任意のものが使用 できる。

SF ピルテスタによるピル生成, 脱落の状態の一例を 図 5 に示した。理論の項で示した 3 段階のステージが本 法によって実際に再現されていることが認められる。

測定の手順は次のとおり。

まず評価しようとする原綿を開綿する。非常に脆い原 綿の場合開綿時における損傷度合がデータに影響するの で任意性のあるハンドカードよりはサンブルカードの方 がよい。含気率を一定の值にするためにはサンプルの比 重によってサンプル量を調節せねばならないが, アクリ ル緎維に限定した場合はサンプル量で一義的にきまる。 試料はできるだけ均一にホルダにつめこみ，一定の王力 下でブラッシングする。ブラッシングの目的はホルダ表

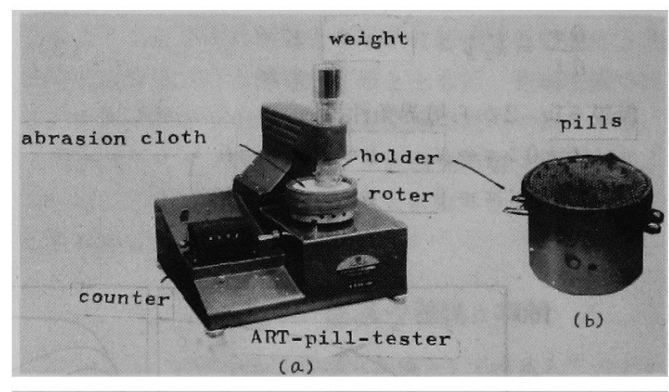

Fig. 4 Appearance of SF-pill-tester

Table 1 Testing condition of SF-pill-tester

\begin{tabular}{c|l}
\hline $\begin{array}{c}\text { Abrasion cloth } \\
\text { Weight }\end{array}$ & $\begin{array}{l}\text { Polypropylene screen mesh (150 mesh) } \\
700 \mathrm{~g} \text { (Total weight } 993 \mathrm{~g})\end{array}$ \\
Weight of Sample & $700 \mathrm{mg}$ (percentage of emptiness $89.5 \%)$ \\
Brushing & $\begin{array}{l}\text { Cut the fużz to } 5 \mathrm{~mm} \text { length after } \\
\text { brushing to make enough fuzz }\end{array}$ \\
Rotating Speed & $100 \mathrm{rpm}$ \\
Number of Samples & 3 \\
\hline
\end{tabular}




\begin{tabular}{|c|c|c|}
\hline Time (min) & Picture & Stage \\
\hline & 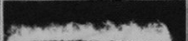 & Fuzz \\
\hline $1 / 10$ & $\operatorname{nex} 2-2 \lambda-\lambda$ & \multirow{4}{*}{ Pill formation } \\
\hline $1 / 4$ & - & \\
\hline $1 / 2$ & as $=$ & \\
\hline 1 & 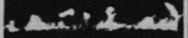 & \\
\hline 2 & nis $\rightarrow$ at & \multirow{4}{*}{ Pill wear ing-off } \\
\hline 3 & | & \\
\hline 4 & 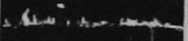 & \\
\hline 5 & $x=m$ & \\
\hline
\end{tabular}

Fig. 5 Proceeding of each stage from pill formation to wearing-off by using SF-pill-tester

面に毛羽立てを行ならためであるので特に方法は関係し ないが，市眅の“エチケットブラシ”が最も扱いやすい。 图 5 程度に十分毛羽立てた後，長すぎる毛羽を八廿ミで カットして毛羽長さを約 $5 \mathrm{~mm}$ とする。この毛羽立ての 程度によって後のピル生成度合は大きく左右されるが, ある程度の任意性はさけられない。そのために後述の標 準化という手段が必要となる。

この状態がステージー1である。ピル形成可能毛羽数 は $X_{0}$ である。

次に毛羽立てられたホルダを試験機にとりつけ, 表 1 の条件下で回転摩擦し，所定の各時間每に生成し残存し ているピル数, 摩擦され脱落したピルの数を読む（ステ
-シ் - 2)。

アクリル絨維の場合, $5 \mathrm{~min}$ 摩擦すれば, ほぼすべ ての毛羽がピルとなる傾向があり，最大回転時間を 5 $\min$ とし, その際の残存ピル数と脱落ピル数の合計を $X_{0}$ とする。

データシートの一例を表 2 として示す。

まず表 $2 \mathrm{a}$ は測定した生データの 3 回の平均値であり $X_{0}$ は $5 \mathrm{~min}$ 時の全ピル数 : 25.6 である。しかしこの $X_{0}$ は任意性があるので再現性には自信がない。ここで標準 化の手段をとる。すなわち， $X_{0}=100$ とし, これを規準 として計算しなおしたのが表 2 bである。

ここで $t=1 / 4$ 時のピル数を読めば 64.4 となり, 図 2 から $k_{1}$ は 4.18 となる。また $k_{1} \div 4$ のときの $k_{2}$ は図 $3 \mathrm{a}$, bから 0.19 となる。すなわちこのデータから $k_{1}=4.18$, $k_{2}=0.19$ の理論曲線で示されるピル生成, 脱落傾向を 示すサンプルであることがわかる。

またこのデータからピル脱落曲線を画くことができ， 脱落ピル数が 50 個に達するに要する時間(半減期-Half Wear-off time - HWT ) を求めれば, この時間が短 いほど抗ピル性があると判断することができる。

\section{2 実験結果}

(1) 試料の作成 ${ }^{8)}$

ジメチルスルホキシド中でフゾニトリル系の重合触媒 を用い, アクリロニトリル/アクリル酸メチル/アリル スルホン酸ソーダ $=97.0 / 2.0 / 1.0$ モル\%の組成で溶液 重合を行ない $[\eta]=1.20$, 原液濃度 $21.0 \%$ の紡系原液を 作成した。上記原夜を表 3 に示す条件で紡系し 3 種類の 試料を得た。それぞれの試料の繊維物性は表 4 に示した。 次にSFピルテスタによる測定結果を表 5 にまとめた。 数値は標準化後の値である。

生成ピル曲線, 脱落ピル曲線および残存ピル曲線(ピ ルライフ曲線)を図 $6 \mathrm{a}$ ，bに示した。また測定値から計 算された $k_{1}, k_{2}$ を理論式にあてはめ理論曲線を求めた

Table 2 Some example of data sheet

a. Original data $\left(X_{0}=25.6\right)$

\begin{tabular}{|c|c|c|c|c|c|c|c|c|c|}
\hline ame & 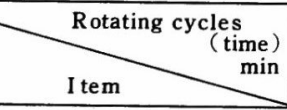 & $\begin{array}{c}10 \\
(1 / 10)\end{array}$ & $\begin{array}{l}25 \\
1 / 4\end{array}$ & $\begin{array}{l}50 \\
1 / 2\end{array}$ & $\begin{array}{r}100 \\
1\end{array}$ & $\begin{array}{c}200 \\
2\end{array}$ & $\begin{array}{c}300 \\
3\end{array}$ & $\begin{array}{c}400 \\
4\end{array}$ & $\begin{array}{c}500 \\
5\end{array}$ \\
\hline \multirow{4}{*}{ A } & $\mathrm{N}$ of remaining pill & 12.5 & 16.5 & 20.0 & 20.3 & 17.5 & 15.3 & 13.3 & 10.3 \\
\hline & $\mathrm{N}$ of wear-off pill & 0 & 0 & 0 & 1.0 & 3.5 & 3.5 & 4.0 & 3.3 \\
\hline & Total $\mathrm{N}$ of wear-off pill & 0 & 0 & 0 & 1.0 & 4.5 & 8.0 & 12.0 & 15.3 \\
\hline & Total $\mathrm{N}$ of wear-off & 12.5 & 16.5 & 20.0 & 21.3 & 22.0 & 23.3 & 25.3 & 25.6 \\
\hline
\end{tabular}

b. Standardized data $\left(X_{0}=100\right)$

\begin{tabular}{l|l|cccrcrrr}
\hline \multirow{4}{*}{ A } & N of remaining pill & 48.8 & 64.4 & 78.1 & 79.2 & 68.3 & 59.7 & 50.7 & 40.2 \\
& N of wear-of f pill & 0 & 0 & 0 & 3.9 & 13.6 & 13.6 & 15.6 & 12.8 \\
& Total N of wear-of pill & 0 & 0 & 0 & 3.9 & 17.5 & 31.2 & 46.8 & 59.7 \\
& Total N of pill & 48.8 & 64.4 & 78.1 & 83.2 & 85.9 & 91.0 & 97.6 & 100.0 \\
\hline
\end{tabular}


Table 3 Preparing conditions of samples

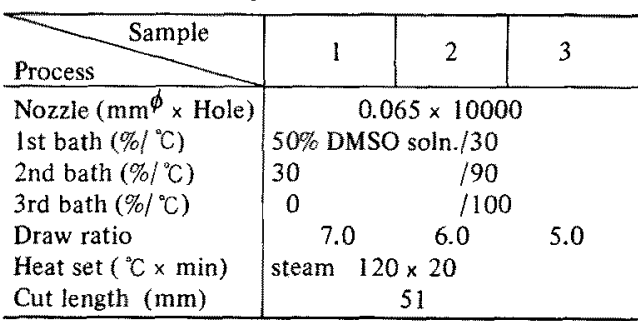

Table 4 Tensile properties of samples

\begin{tabular}{l|c|c|c}
\hline Item Samples & 1 & 2 & 3 \\
\hline Denier (d) & 2.96 & 2.90 & 2.79 \\
Tenacity (g/d) & 3.44 & 3.21 & 3.01 \\
Elongation (\%) & 27.5 & 30.6 & 30.0 \\
Knot tenacity (g/d) & 1.55 & 1.32 & 1.47 \\
Knot elongation (\%) & 11.8 & 9.8 & 12.0 \\
Loop tenacity (g/d) & 1.50 & 1.27 & 1.56 \\
Loop elongation (\%) & 2.9 & 2.4 & 1.9 \\
\hline
\end{tabular}

Table 5 Result of SF pill test

\begin{tabular}{|c|c|c|c|c|}
\hline \multicolumn{2}{|c|}{$\underbrace{\text { Rotating }}_{\text {Item }}$ Sample } & 1 & 2 & 3 \\
\hline \multirow{8}{*}{$\begin{array}{l}\mathrm{N} \text { of } \\
\text { Remaining pill } \\
\left(\begin{array}{l}\mathrm{N} \text { of } \\
\text { wear-off pill }\end{array}\right)\end{array}$} & $1 / 10$ & $46.2(0)$ & $43.2(0)$ & $45.5(0)$ \\
\hline & $1 / 4$ & $65.3(0)$ & $60.0(0)$ & $60.4(1.6)$ \\
\hline & $1 / 2$ & $72.9(0)$ & $75.5(0)$ & $71.1(5.9)$ \\
\hline & 1 & $85.0(0)$ & $88.4(1.9)$ & $68.4(16.6)$ \\
\hline & 2 & $71.1(13.3)$ & $81.9(8.4)$ & $58.8(31.6)$ \\
\hline & 3 & $57.8(32.4)$ & $69.0(29.7)$ & $44.4(47.6)$ \\
\hline & 4 & $47.2(49.7)$ & $40.6(57.4)$ & $33.7(66.3)$ \\
\hline & 5 & $38.7(61.3)$ & $27.7(72.3)$ & $16.0(84.0)$ \\
\hline$k_{1}$ & & 4.25 & 3.74 & 3.74 \\
\hline$k_{2}$ & & 0.21 & 0.26 & 0.34 \\
\hline HWT $(\min )$ & & 4. 15 & 3.90 & 3.05 \\
\hline
\end{tabular}

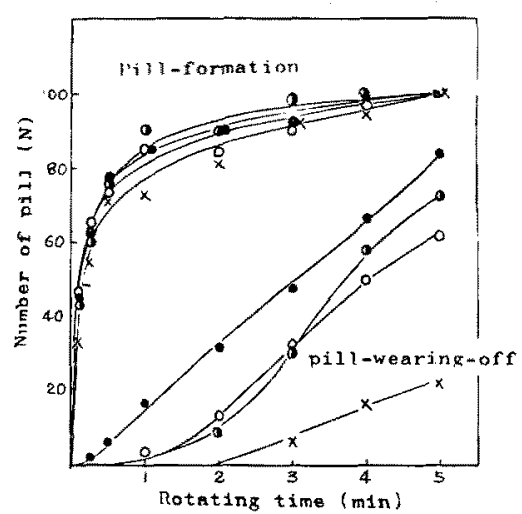

(a) Pill-formation and pill-wearing-off curves

O Sample No. 1

- No. 2

- No. 3

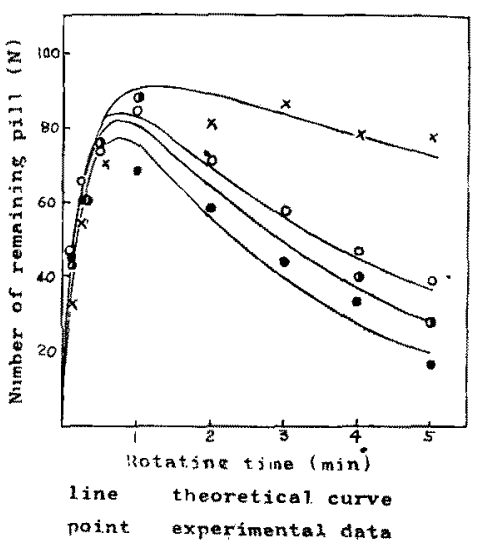

Fig. 7 Relation between theoretical curve and experimental data

結果を图 7 に実験値と刘比して示した。寒駼値は理論値 ときかめてよい一致を見せて抽，理諭の項で設定した 仮説にはさほど無理がないことが墕められる。

水牮間には $k_{2}$ ，HWTに見られる上うに明らかな差が あり，延伸倍率が低い方が抗ビル性がありそうだ。原綿 物性との対伈は引卦伸度との間に相関が認められるが他 の特性值では 3 水漬間の差を十分検知することができな

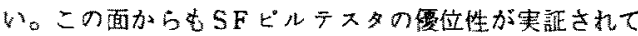
いる。

また上記原綿を紡績，編成した後のICI 型ピリング試 験機に扔ける抗ビル試験結果との成係は闵 8 に亦した。

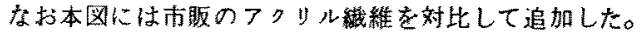
$k_{2}$, HWTともにきわめてよい相関が認められ，原綿段 階から抗ビル性の推定が可能であることを示している。

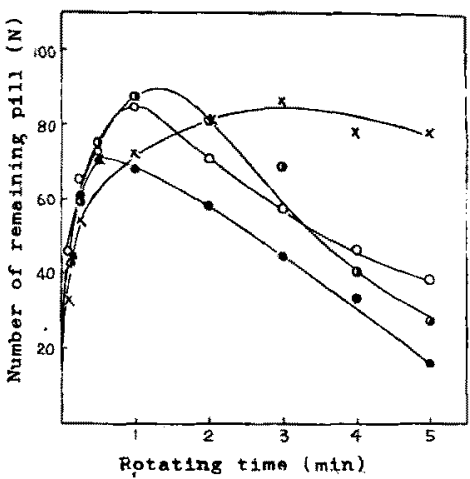

(b) Pill life curves

$\times$ Commercialized acrylic "Toraylon"

Fig. 6 Experimental curve of each sample compared with commercialized acrylics "Toraylon" 

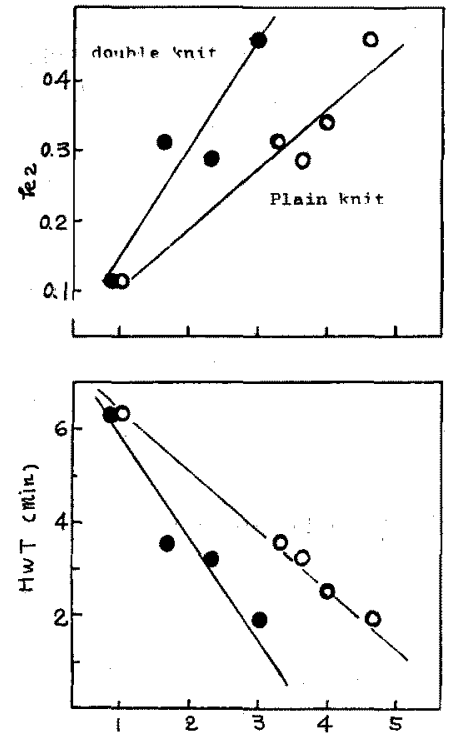

ICI pilling tendency (grade)

Fig. 8 Relation between $k_{2}$ or HWT and actual pilling tendency as knit fabric by ICI-pill-tester

\section{4. 考察}

ピルの生成，脱落過程を定量的に把晊するためには， その第1段階である“毛羽発生”の度合を定量化する必 要がある。実際に抗ビル繊維の場合，ピル脱落を助長す るような方法で作成された原綿でも高次加工因子により その抗ピル性は大きく変化する。中でも編織物の組織は 抗ピル性に対する影響が大きいことは図 8 で明らかであ る。

しかしながら原綿を制造する立場からすれば，毛羽発 生を防止する方法で原綿が抗ピル化されていない以上， 原綿の抗ピル性の目安はピル脱落助長度合を比較せざる を得ない。そのためには高次加工工程あるいは製品化後 の毛羽発生はやむをえないとして，むしろ十分に毛羽が 発生するとして，その毛羽を源として発生したピルがど の程度早く落ちるかを調べることが必要となる。

そのためには発生する毛羽数を十分多くかつ一定值に 保つことが重要なのであるが, 発生毛羽の一定化は操作 上籍密に住困難であり，できるだけ合わせるよう注意す るしか力法がない。そのため標準化という計算を行ない 常に発生したピル数は一定という操作を行なう。その際 全ピル数を 100 と扔く意味は換言すれば，生成した全ビ ル数に詨する百分比(パーセンテージ)で示したことで ありビルの絶対值ではなく相対的な生成脱落の傎向を 見ているわけである。
高次加工因子を考慮せず，原綿自体の抗ピルポテンシ ヤルを判定するためであれば，これで十分ではないかと 考える。

このようにかなり強引とも思える仮定の下に尊びかれ た理諭ピルライフ曲線てはあったが，図7に見られるよ うに夷験值との間には驚くほどのよい対応関係が認めら れ，十分事実を反映しているとみなすことができよう。

特にこの仮定の中ではピルとならない毛羽の量という ものが無視され，発生した毛羽はすバてピルとなり脱落 するという項があるが，肃際にはこのプロセスの影響は 少なく，仮定に無理がなかったことを示している。

かくしてピル生成脱落の過程を一次の速度式からかな りすっきりした形て理論的に解明することができたが， これを聿証する㬰験方法は上述の事妻があるとはいえ以 下の問题点が残っている。
A）解綿方法に任意性がある。
B）毛羽立ての程度に任意珄がある。
C ）ピルの判定に任意性がある。
D) 摩擦布が経時変化打る。

このうち上䓰 3 点は任意性の問題であり，(1)はサン ブルカードがあれば解決するが，どこにでもあるもので はないのてたいがいはハンドカードを利用することに なる。（2）は今のところ擗けられないので標準化加必要 てある、また(る)は一般によく利用されているICI型ピ リング試験機の場合にも同様の不安があり，標潗写真を 作るが，判定者を訓練する必要がある。(4)仙耐用限界 を奏験すれ怗よい。

以上の問題点については次報で詳細に解明する予定で ある。

\section{5. 総括}

原綿で抗ピル性を判定する新しい万法として，SFピ ルテスタを用いてピルライフ曲線を画き，これを解析す ることが有效であることがわがった。

1）ピル生成，脱落の機構は次のプロセスを仮定した とさ，次式で理論的に表わしうる。

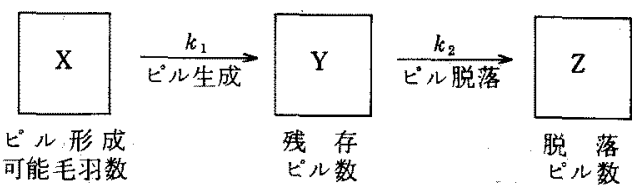

$$
\begin{aligned}
& y=\frac{k_{1} X_{0}}{-k_{1}+k_{2}}\left(e^{-k_{1} t}-e^{-k_{2} t}\right) \\
& \left(\begin{array}{l}
k_{1}: \text { :゚ル生成速度定数 } \\
k_{2}: \text { :゚ル脱落速度定数 }
\end{array}\right)
\end{aligned}
$$


2) SFピルテスタからもとめたビルライフ曲線を上 式にあては， $k_{2}$ ，HWTをもとめ $k_{2}$ が大きくHWTが 小さいほど抗ピル性があると判定する。

\section{文献}

1）例えば，特公昭 45-11480，46-15147など

2）例えば，特公昭 36-6190，41-17040，41-20416, 45-7692, USP 3332832,3108356 ,
BP 1003697 など

3）幾機学会編；基礎織維工学〔1〕,p.146(1976)

4) Grunewald ; Chemiefasem,12,835(1962)

5) DuPont ; Neth 300965 (1965)

6) 特公昭 41-20416(1966)

7) R. H. Brand ; Text. Res.J. 37, 467(1967)

8）特公昭 47-2776(1972)

9）奉公昭 44-4643(1969)

10) 辻本石雄, 元治信雄; 緎学誌, 20,768(1964)

(昭和 50 年 4 月 25 日受理)

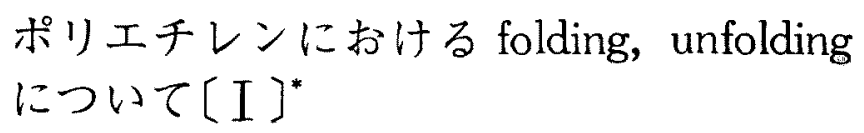

ュニチカ拣式会社中央研究所田川高司・田絧稔英

鹿息勝

\title{
CHAIN FOLDING AND UNFOLDING IN POLYETHYLENE (I)
}

\author{
By Takashi Tagawa, Toshihide Tabuchi and Masaru Kashima \\ (Research \& Development Center, UNITIKA Ltd. \\ 23 Kozakura, Uji, Kyoto 611 , Japan)
}

\begin{abstract}
The present paper gives a method to evaluate fold-content, $C_{f}$ in polyethylene (PE) from IR measurement $\left(1200-1400 \mathrm{~cm}^{-1}\right)$. Solution-grown crystals of n-paraffin and PE were adopted as standard specimen containing no fold $\left(C_{f}=0\right)$ and $100 \%$ fold $\left(C_{f}=1.0\right)$, respectively and mixtures of these substances were used for the determination of constants, $k$ and $K$, in Koenig's equation. The values of $C_{f}$ obtained from two pair of absorption bands (from each sample) showed good agreement for various $\mathrm{PE}$ samples.
\end{abstract}

(Received April 25, 1975)

\section{1. 緒 言}

ポリエチレン、ナイロン6，66，PETなど，多くの結 晶性高分子が，固体中で折りたたみ鎖からなるラィラ構 造をとることはよく知られている。また，末延伸構造体 中のラメラの折りたたみ分子鎖が延伸によって解きほぐ され，㵶維搆造にうつること，熱姏理によって一たん形 成された瀻維構造からラィラ構造が再生されることも周 知のことがらである。これらの現象は, 分子鎖の unfoldingやrefoldingで巧く説明されるが，このような 機構が考えられるに至った根拠の多くは、これまで単結
晶や固体表面について、答形、熱処理にともなうモルホ 口ジーの変化を追った多くの電子顕砫鏡観祭の結果にあ ると思われる。このように、電子顕制鏡はこの方面の研 究に有力な情報をもたらすが，電子影溦鏡といえども， 微細なラ゙ィラの一敕一枚を捉えることは。条件が整わぬ かぎりなかなか容易でないし、まして、ラメラ中の個々の 分子鎖や，変形中のラメラの動き，folding, unfolding しつつある分子鎖の挙動を直接観察することは，現在の ところ，不可能と云ってもよいであろう。

高分子固体中の foldの状悲をX線による測定から調 ベようとした試みも一，二みられるが1,2)，foldに関す る直接的な情報をえることにはかなりの困難があるよう に思われる。この点, 郝攻収スベクトルはポリマー鎖

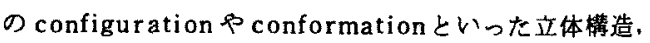

